\title{
Study and Application of Bio-cementation Technique on Soil Improvement
}

\author{
Xingyun Guo ${ }^{1,2}$, Chunxu $\mathrm{Ji}^{1}$, Yongkang Yang ${ }^{1,2,3, *}$ \\ ${ }^{1}$ Institute of Mining Technology, Taiyuan University of Technology, Taiyuan, Shanxi 030024, China \\ ${ }^{2}$ Department of Mining Engineering and Metallurgical Engineering, Curtin University, WA 6430, \\ Australia \\ ${ }^{3}$ State Key Laboratory for GeoMechanics and Deep Underground Engineering, China University of \\ Mining \& Technology, Xuzhou 221008, China \\ *Corresponding author: yangyongkang@tyut.edu.cn
}

Keywords: Bio-cementation, soil improvement, microbial induced calcite precipitation (MICP)

\begin{abstract}
Bio-mediated geo-technology is a new branch of geotechnical engineering that amends the mechanical properties of soil by using microbiological methods to construction materials. As a new and emerging technique, the bio-cementation process needs to be studied further in various aspects. This paper potentially provide a reference and guide for further research in the relevant fields. The findings are useful to determine the optimal parameters of bio-cementation application.
\end{abstract}

\section{Introduction}

In recent years, in order to stimulate industrial renewal, research in civil engineering has been inspired by many techniques imported from other domains such as chemistry and biology. Biocementation, as one of biologically mediated processes, has been used for soil improvement to mitigate liquefaction, erosion, and improve strength and hydraulic properties of soils, with the view of replacing the old techniques based on the injection of cement. Cement has been found to be one of the world's leading sources of $\mathrm{CO}_{2}, \mathrm{NO}_{\mathrm{x}}$ (nitrogen oxides), and airborne particulate matter emissions (Chang, Im, Prasidhi, \& Cho, 2015). Compared to the traditional techniques, biocementation is commercially available and environmental friendly.

Mineralization induced by microbial activities is a common phenomenon in nature. Certain microorganisms naturally present in the soil can use their own metabolic activities to generate a variety of mineral crystals. The process of bio-cementation is based on the activity of bacteria that are able, by their metabolic activity, to induce the hydrolysis of urea $\left(\mathrm{CO}\left(\mathrm{NH}_{2}\right)_{2}\right)$ and the production of anions of carbonate $\left(\mathrm{CO}_{3}{ }^{2-}\right)$. One of the commonly used bacteria for this process is Sporosarcina Pasteurii. In the presence of excess calcium ions, the carbonate $\left(\mathrm{CO}_{3}{ }^{2-}\right)$ released during the hydrolysis reacts with the calcium $\left(\mathrm{Ca}^{2+}\right)$, leading to the precipitation of crystals of $\mathrm{CaCO}_{3}$ (Hammes \& Verstraete, 2002).

When these crystals form coatings on or bonds between the existing soil particles, they prevent movement of the particles, thereby improving the physico-mechanical properties of the treated 
materials. Several researchers have shown that the bio-cementation has many advantages such as small disturbance, less environmental harm, and remarkable treatment effect on improvement of soil properties (cohesion, stiffness, and liquefaction resistance), which bring about a broad application prospect in geotechnical and environmental engineering (Chu, Ivanov, Naeimi, Stabnikov, \& Liu, 2014; Ivanov \& Chu, 2008; Qian, Wang, \& Wang, 2015).

However, as a new and emerging technique, the bio-cementation process needs to be studied further. Its research and application on soil improvement is less well-documented in the literature. Therefore, the aim of this work is to review the application of bio-cementation technique for soil improvement. The paper is structured as follows: firstly, the soil improvement system induced by bio-cementation technique is introduced. Secondly, based on previous research, the commonly used evaluation methods for the bio-cementation performance induced by bio-mediated are discussed in detail. Lastly, the limitations and potential problems are discussed. This paper makes an original contribution to knowledge about the bio-cementation. Also, it is useful to facilitate its engineering application.

\section{Soill Improvement System Induced by Bio-cementation}

A bio-amended soil improvement system generally refers to reaction conditions, microbial activities, and amended soil properties. In other words, the process of bio-cementation works within the system under a certain condition, thereby improving the mechanical properties of the bioamended soil materials.

The reaction conditions broadly contained several important parameters, such as choosing the type of bacteria, the concentration of chemicals products, the time contact between bacteria and soils. Bacillus pasteurii is one of commonly used bacteria. These parameters significantly affect the microbial activities and thus change the effectiveness of bio-cementation. The bio-cementation performance obtained in columns will be compared to that obtained by direct deposition of bacteria and products in the soils as described by Grabiec et al (Grabiec, Starzyk, Stefaniak, Wierzbicki, \& Zawal, 2017).

In most of relevant studies, the bio-cementation process is based on the metabolic activities of certain bacteria. It can be categorized into two main steps, the decomposition of urea and the precipitation of calcium carbonate crystals. This process is performed as follows:

$$
\begin{gathered}
\mathrm{CO}\left(\mathrm{NH}_{2}\right)_{2}+\mathrm{H}_{2} \mathrm{O} \rightarrow \mathrm{CO}_{2}+2 \mathrm{NH}_{3} \mathrm{pH}^{\uparrow} \\
2 \mathrm{NH}_{3}+\mathrm{CO}_{2}+\mathrm{H}_{2} \mathrm{O} \rightarrow 2 \mathrm{NH}_{4}{ }^{+}+\mathrm{CO}_{3}{ }^{2-} \\
\mathrm{Ca}^{2+}+\mathrm{CO}_{3}{ }^{2-} \rightarrow \mathrm{CaCO}_{3}(\mathrm{~s}) \quad \mathrm{pH} \downarrow
\end{gathered}
$$

The microbial activities take place when bacteria and soils contact in nature. In laboratory experiments, the reagents are provided by calcium chloride solution and nutrition solution. An overview of the bio-cementation process is presented schematically in Fig 1.

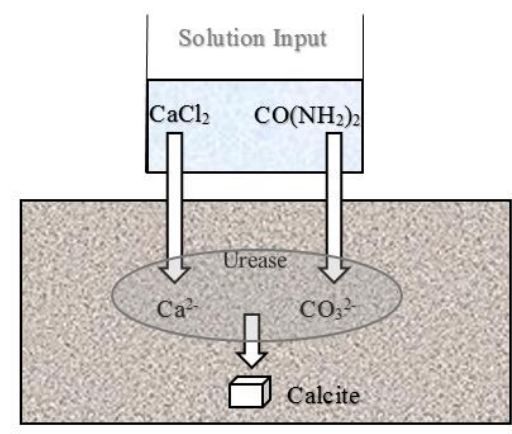

Figure 1 Schematic of bio-cementation process 
The mechanical properties of soil materials are important for engineering constructions, such as dam, dikes, and pier. The improvement of mechanical properties (cohesion, stiffness, and volumetric response) can be achieved after the bio-cementation. The study conducted by Dejong et al (DeJong et al., 2010) showed that at a speed of 600 to $1100 \mathrm{~m} / \mathrm{s}$ (initial shear wave velocity of $100 \mathrm{~m} / \mathrm{s}$ ), the shear stiffness is significantly increased.

\section{Evaluation Methods}

A variety of methods have been used to evaluate the performance of bio-cementation in the literature. The commonly used evaluation methods are categorized into two main groups, including mechanical tests, and physico-chemical and microscopy tests. Concerning the mechanical tests, they broadly are two key types, namely static mechanical tests and dynamic mechanical tests. Also, the cubic mould and cylinder mould are commonly used in these tests. Table 1 summarizes several representative papers that focused on the study of bio-cementation on the improvement of mechanical properties.

Table 1 Summary of representative studies for bio-cementation technique

\begin{tabular}{|c|c|c|c|}
\hline Reference & $\begin{array}{c}\text { Evaluation } \\
\text { method }\end{array}$ & Test brief & Main conclusion \\
\hline $\begin{array}{l}\text { (DeJong, } \\
\text { Fritzges, \& } \\
\text { Nüsslein, 2006) }\end{array}$ & $\begin{array}{l}\text { Undrained shear } \\
\text { strength tests; } \\
\text { X-ray } \\
\text { compositional } \\
\text { mapping. }\end{array}$ & $\begin{array}{l}\text { The sand sample diameter is } 72 \\
\text { mm and the height is } 144 \mathrm{~mm} \text {; } \\
\text { Ottawa sand } \mathrm{D} 50=0.12 \mathrm{~mm} \text {. }\end{array}$ & $\begin{array}{l}\text { Undrained shear strength } \\
\text { increases about } 4 \text { times } \\
\text { (confining pressure is } 100 \\
\mathrm{kPa} \text { ). }\end{array}$ \\
\hline $\begin{array}{l}\text { (Whiffin, van } \\
\text { Paassen, } \quad \& \\
\text { Harkes, 2007) }\end{array}$ & $\begin{array}{l}\text { Confined drained } \\
\text { tri-axial tests }\end{array}$ & $\begin{array}{l}\text { The sand sample diameter is } 66 \\
\mathrm{~mm} \text { and the height is } 5 \mathrm{~m} \text {; } \\
\text { Itterbeck sand }(125-250 \mu \mathrm{m}) \text {. }\end{array}$ & $\begin{array}{l}\text { Consolidation drainage } \\
\text { intensity is 200 570 kPa } \\
\text { (confining pressure is } 50 \\
\mathrm{kPa} \text { ). }\end{array}$ \\
\hline (Li, 2014) & $\begin{array}{l}\text { Unconfined } \\
\text { compression tests }\end{array}$ & $\begin{array}{l}\text { The sand sample is } \\
1.12 * 0.96 * 0.95 \mathrm{~m} \text {. }\end{array}$ & $\begin{array}{l}\text { Unconfined compressive } \\
\text { strength is } 10 \sim 1400 \mathrm{kPa} \text {. }\end{array}$ \\
\hline $\begin{array}{l}\text { (L. Van Paassen } \\
\text { et al., 2009) }\end{array}$ & $\begin{array}{l}\text { Unconfined } \\
\text { compression } \\
\text { tests; } \\
\text { Cone penetration } \\
\text { tests. }\end{array}$ & $\begin{array}{l}\text { The sand sample is } \\
0.9 * 1.1^{*} 1.0 \mathrm{~m} \text {. }\end{array}$ & $\begin{array}{l}\text { The shallow cone } \\
\text { penetration resistance is } \\
\text { up to } 5 \mathrm{MPa} \text {, and the } \\
\text { uniaxial compressive } \\
\text { strength of the sand } \\
\text { sample is up to about } 9 \\
\text { MPa. }\end{array}$ \\
\hline $\begin{array}{l}\text { (Yasuhara, } \\
\text { Neupane, } \\
\text { Hayashi, \& } \\
\text { Okamura, 2012) }\end{array}$ & $\begin{array}{l}\text { Unconfined } \\
\text { compression } \\
\text { tests; }\end{array}$ & $\begin{array}{l}\text { The sand sample diameter is } 50 \\
\mathrm{~mm} \text { and the height is } 100 \mathrm{~m} \text {. }\end{array}$ & $\begin{array}{l}\text { The uniaxial compressive } \\
\text { strength of the sand } \\
\text { sample ranges from } \\
400 \mathrm{kPa} \text { to } 1.6 \mathrm{MPa} \text {. }\end{array}$ \\
\hline $\begin{array}{l}\text { (Harkes, Van } \\
\text { Paassen, } \\
\text { Booster, } \\
\text { Whiffin, \& van } \\
\text { Loosdrecht, } \\
\text { 2010) }\end{array}$ & $\begin{array}{l}\text { Optical density } \\
\left(\text { OD }_{600}\right) ; \\
\text { Urease activity } \\
\text { monitoring; } \\
\text { Ammonium } \\
\text { concentration. }\end{array}$ & $\begin{array}{l}\text { A spectrophotometer with a } \\
600 \text {-nm wavelength was used } \\
\text { for optical density; A modified } \\
\text { Nessler method was used to } \\
\text { determine } \\
\text { concentration. }\end{array}$ & $\begin{array}{l}\text { OD retained ranges from } \\
14 \text { to 99\%; activity } \\
\text { retained ranges from } 17 \\
\text { to } 93 \% \text {. }\end{array}$ \\
\hline
\end{tabular}




\section{Limitations and Potential Problems}

As a new and emerging technique, the bio-cementation process have some limitations that needs to be studied further. A major problem is that homogeneous bio-cementation is difficult to be obtained in situ, especially when the amount of precipitated carbonate is low. The homogeneous bio-cementation is considered crucial to geotechnical applications in practice. In previous studies, several researchers have carried out relevant studies focused on this problem. For example, Paassen et al. (Van Paassen, Whiffin, \& Harkes, 2009) revealed that the heterogeneous of bio-cementation mainly results from the differences between injection rate and decomposition rate. Considering this limitation, several studies give suggestions for performance enhancement, such as using various injection procedure, adjusting injection rate, and increasing injection pressure (A Al Qabany \& Soga, 2013; Ahmed Al Qabany, Soga, \& Santamarina, 2011; Barkouki et al., 2011).

Moreover, most works were carried out on fine sands, even if it is known that the materials used for dikes and dams are coarser than fine sands. Another main limitation is the sustainability of biocemented after treatment. This will be studied in order to evaluate the feasibility of using these materials under real conditions(Ivanov \& Chu, 2008).

\section{Conclusion}

Focused on the bio-cementation technique for soil improvement, this review papaer described the soil improvement system induced by bio-cementation technique from three different aspects, namely the reaction conditions, microbial activities, and amended soil properties; summarized the commonly used methods for evaluating the performance of bio-cementation; also, the major limitations or problems were described in detail.

\section{Acknowledgement}

This work was financially supported by the China Postdoctoral Science Foundation (No.2016M590151), the State Key Laboratory for GeoMechanics and Deep Underground Engineering (No. SKLGDUEK1410), the National Natural Science Foundation of China (No.51404167).

\section{References}

[1] Al Qabany, A., \& Soga, K. (2013). Effect of chemical treatment used in MICP on engineering properties of cemented soils. Géotechnique, 63(4), 331.

[2] Al Qabany, A., Soga, K., \& Santamarina, C. (2011). Factors affecting efficiency of microbially induced calcite precipitation. Journal of Geotechnical and Geoenvironmental Engineering, 138(8), 992-1001.

[3] Barkouki, T., Martinez, B., Mortensen, B., Weathers, T., De Jong, J., Ginn, T., . . Fujita, Y. (2011). Forward and inverse bio-geochemical modeling of microbially induced calcite precipitation in half-meter column experiments. Transport in Porous Media, 90(1), 23.

[4] Chang, I., Im, J., Prasidhi, A. K., \& Cho, G.-C. (2015). Effects of Xanthan gum biopolymer on soil strengthening. Construction and Building Materials, 74, 65-72.

[5] Chu, J., Ivanov, V., Naeimi, M., Stabnikov, V., \& Liu, H.-L. (2014). Optimization of calcium-based bioclogging and biocementation of sand. Acta Geotechnica, 9(2), 277-285.

[6] DeJong, J. T., Fritzges, M. B., \& Nüsslein, K. (2006). Microbially induced cementation to control sand response to undrained shear. Journal of Geotechnical and Geoenvironmental Engineering, 132(11), 1381-1392.

[7] DeJong, J. T., Soga, K., Banwart, S. A., Whalley, W. R., Ginn, T. R., Nelson, D. C., . . Barkouki, T. (2010). Soil engineering in vivo: harnessing natural biogeochemical systems for sustainable, multi-functional engineering solutions. Journal of the Royal society Interface, rsif20100270.

[8] Grabiec, A. M., Starzyk, J., Stefaniak, K., Wierzbicki, J., \& Zawal, D. (2017). On possibility of improvement of compacted silty soils using biodeposition method. Construction and Building Materials, 138, 134-140. 
[9] Hammes, F., \& Verstraete, W. (2002). Key roles of pH and calcium metabolism in microbial carbonate precipitation. Reviews in environmental science and biotechnology, 1(1), 3-7.

[10] Harkes, M. P., Van Paassen, L. A., Booster, J. L., Whiffin, V. S., \& van Loosdrecht, M. C. (2010). Fixation and distribution of bacterial activity in sand to induce carbonate precipitation for ground reinforcement. Ecological Engineering, 36(2), 112-117.

[11] Ivanov, V., \& Chu, J. (2008). Applications of microorganisms to geotechnical engineering for bioclogging and biocementation of soil in situ. Reviews in Environmental Science and Bio/Technology, 7(2), 139-153.

[12] Li, B. (2014). Geotechnical properties of biocement treated soils. Singapore: Nanyang Technological University.

[13] Qian, C., Wang, A., \& Wang, X. (2015). Advances of soil improvement with bio-grouting. Rock and Soil Mechanics, 36(6), 1537-1548.

[14] Van Paassen, L., Harkes, M., Van Zwieten, G., Van der Zon, W., Van der Star, W., \& Van Loosdrecht, M. (2009). Scale up of BioGrout: a biological ground reinforcement method. Paper presented at the Proceedings of the 17th international conference on soil mechanics and geotechnical engineering.

[15] Van Paassen, L. A., Whiffin, V. S., \& Harkes, M. P. (2009). Immobilisation of bacteria to a geological material: Google Patents.

[16] Whiffin, V. S., van Paassen, L. A., \& Harkes, M. P. (2007). Microbial carbonate precipitation as a soil improvement technique. Geomicrobiology Journal, 24(5), 417-423.

[17] Yasuhara, H., Neupane, D., Hayashi, K., \& Okamura, M. (2012). Experiments and predictions of physical properties of sand cemented by enzymatically-induced carbonate precipitation. Soils and Foundations, 52(3), 539-549. 